\title{
Comparison of the Exam Scores Obtained in Face-to-Face Education and Online Education by the Students of the Faculty of Dentistry
}

\author{
Burcu Duman ${ }^{*}$, Cansu Demiroglu $\odot$ and Mustafa Aydınbelge \\ Department of Pediatric Dentistry, Faculty of Dentistry, Erciyes University, Kayseri, TURKEY \\ *Corresponding Author; burcuduman91@hotmail.com
}

\begin{abstract}
Purpose: The Covid-19 pandemic has affected our daily lives by affecting the whole world and caused our habits to change.One of the effects of the epidemic has been on education.With the spread of the epidemic, online education has become the only way to maintain the normal teaching order.In this case, it directly affects the quality of education received.The aim of this study is to examine whether there is a difference between the exam scores made face to face and online.

Methods: Students who were 3rd grade in 2018-2019 and 4th grade in 2019-2020 academic year were included in the study.The scores that these students got in the Pedodontics Theoretical Exam within two years were evaluated. Exam scores according to time were analyzed with Friedman Test and Wilcoxon Test.

Results: In the 2019-2020 academic year, the median values of the scores obtained from the exams that took the first exam face-to-face and the second and third exams online varied $(\mathrm{p}<0.001)$.The median values of the scores obtained in the online exams (median values of 90 and 95, respectively) (the mean values are 89.6 $\pm 8.7,93.8 \pm 9$, respectively), the median values of the scores obtained from the theoretical exam (median 70, mean 67.2 \pm 18.1 ) was obtained higher.On the other hand,it was observed that there was a significant increase between the scores obtained by the same students from the exams held face-to-face in the previous year (median 74, mean 74.1 \pm 7.1 ) and the scores they took from the online exams they obtained the next year (median 89 , mean $87.7 \pm 9.1)(\mathrm{p}<0.001)$.

Conclusion: The results of the exams made with the online system are higher than the exam scores performed face to face.This may be due to the insufficient control mechanisms of the online exam system.For this reason, online exam security measures should be increased.
\end{abstract}

Key words: exam, face-to-face education, online education

\section{Introduction}

Education is defined as the development process in which change occurs with free will in human beings. ${ }^{1}$ Economic, political, and sociological factors with the development of technology; Internetbased education has increased the importance of easy education in higher education. ${ }^{2}$ One of these various factors has been the Covid-19 pandemic. With the spread of the Covid-19 pandemic, the education plan all over the world was disrupted and our country was affected by this situation. Education has started online education system transitions to prevent education disruption. ${ }^{3}$ Because it has become the only way to maintain the normal education order in the training of the online education pandemic to maintain education order. ${ }^{4}$
Determining the change in the status of the people who receive education at the end of the education process or in the intermediate periods and eliminating the missing parts requires the use of measurement and evaluation methods. The remote implementation of education has also created the measurement and evaluation methods to be performed remotely. ${ }^{1}$ With the development of internet-supported education, some or all of the measurement and evaluation processes can be carried out on the internet. ${ }^{1}$

Educational changes have brought challenges to online education platforms, including the emerging needs of online education, meeting these requirements, and live streaming. ${ }^{4}$ In researches on the evaluation system of online education platforms, it has been observed that there are still some problems such as the lack of certain indicators, unclear evaluation criteria and the accumulation of 
Table 1. Exam scores taken by students according to years

\begin{tabular}{|c|c|c|c|c|c|}
\hline Year & Exams & $\begin{array}{c}\text { Mean } \pm \text { standard } \\
\text { deviation }\end{array}$ & Median (min - max) & $\mathrm{p}^{*}$ & $\mathrm{p}^{* *}$ \\
\hline \multirow{4}{*}{$2019-2020(n=113)$} & 1.Exam(facetoface) & $67,2 \pm 18,1$ & $70(0-99)^{\mathrm{a}}$ & & \multirow{8}{*}{$<0.001)$} \\
\hline & 2. Exam(online) & $89,6 \pm 8,7$ & $90(0-100)^{b}$ & & \\
\hline & 3. Exam(online) & $93,8 \pm 9$ & $95(0-95)^{c}$ & $<0.001)$ & \\
\hline & Total & $87,7 \pm 9,1$ & $89(0-95)$ & & \\
\hline \multirow{4}{*}{$2019-2020(n=97)$} & 1.Exam(facetoface) & $72,8 \pm 10,2$ & $74(37-92)^{d}$ & \multirow{4}{*}{$<0.001)$} & \\
\hline & 2. Exam(facetoface) & $77,9 \pm 11,2$ & $79(29-96)^{\mathrm{e}}$ & & \\
\hline & 3. Exam(facetoface) & $58,9 \pm 14,3$ & $62(17-84)^{f}$ & & \\
\hline & Total & $74,1 \pm 7,1$ & $74(60-88)$ & & \\
\hline
\end{tabular}

* Friedman Test, ** Wilcoxon Test, a-f: There is no difference between times with the same letter. n: Total of students number.

grade distributions in certain scores. ${ }^{4}$ For this reason, our aim in this study is to examine whether there is a difference between the exam scores made face to face and online.

\section{Methods}

Students who were 3rd grade in 2018-2019 and 4th grade in 20192020 academic year were included in the study. 113 "3rd grade" students and 97 "4th grade" students participated in the study. The scores that these students got in the Pedodontics Theoretical Exam within two years were evaluated. Data were analyzed with IBM SPSS V23 (Chicago, USA). The suitability of the values to the normal distribution according to the groups was examined by KolmogorovSmirnov test. Exam scores according to time were analyzed with Friedman test and Wilcoxon Test. Analysis results are presented as mean \pm standard deviation and median (minimum - maximum) for quantitative data. The significance level was evaluated as $\mathrm{p}<0.05$.

\section{Results}

The median values differ according to the scores taken from the exams in the 2019-2020 academic year, which includes the year 2020 when the pandemic was seen in our country $(\mathrm{p}<0.001)$. The median value was 70 in the 1 st exam, 90 in the 2 nd and 95 in the $3 \mathrm{rd}$. While the highest median was in the 3rd exam, the lowest median was obtained in the 1st exam. It has been observed that the median values of the 2nd and 3rd exams, which are the exams with online exams, have increased.

When the Pedodontics exam scores of the same students in the previous academic year (2018-2019) were examined, it was seen that there was a statistically significant difference between the median values of the exam scores made during the year $(\mathrm{p}<0.001)$. However, it was seen that this difference was due to the decrease in median values, unlike the pandemic period. The median value obtained in the first exam was 72.8, in the second exam it was 77.9, while the median value in the final exam was 58.9.

It was also observed that there was a difference between the scores obtained from the Pedodontics theoretical exam in the 20182019 academic year, when all exams were held face-to-face, and the first exam in the 2019-2020 academic year, when the last two exams were held face-to-face $(\mathrm{p}<0.001)$. (Table 1 )

\section{Discussion}

Online education draws attention with its many advantages compared to face-to-face training. However, these advantages are effective when distance education is designed and implemented correctly. ${ }^{2}$ As in all educational levels, it is aimed to ensure that university students can easily access information, contribute to production by using knowledge, and raise individuals with critical and creative thinking skills. ${ }^{5}$ In order to be able to evaluate whether they have gained their skills or not, an assessment and evaluation unit should be established, an infrastructure should be established, security measures should be provided for students to access exam applications. ${ }^{6}$ Measurement and evaluation criteria (exam duration, number of access, evaluation of exam scores, etc.) should be determined well. ${ }^{1}$

There are various discussions regarding the safety of exams in online education. Some of these are situations such as cheating widely and student achievement cannot be determined objectively. It is very important to provide the necessary conditions in terms of ensuring the safety of the exam and being an objective application in exams conducted online and without supervision. ${ }^{6}$

In a study, the same lesson was given to different groups with online education and face-to-face education, and there was no difference between the exam results of the experimental and control groups. ${ }^{7}$ In another study, it was reported that the exam scores of students taking web-based courses were $5 \%$ higher than those who received face-to-face education. ${ }^{8}$ As a result of our study, it was observed that the exam results made with online education were high. We think that the different results of the studies are due to the difference in the security measures of the exams.

\section{Conclusion}

Covid-19 has increased the importance of online education in universities during the pandemic process. Online education applications, which are rearranged as blended with face-to-face education, are the most important investment for universities in the future. For this reason, it is of great importance to increase the inspection mechanisms and security measures of online exam systems.

\section{Author Contributions}

BC, CD: Designed the study, Reviewed literature, wrote manuscript; MA: Contributed substantially to discussion.

\section{Conflict of Interest}

Authors declare that they have no conflict of interest.

\section{Authors' ORCID(s)}

B.C. $0000-0002-1298-8509$

C.D. $0000-0002-3619-5626$

M.A. 0000-0003-3610-4031 


\section{References}

1. Calli I, Torkul O, Tasbasi N. İnternet destekli öğretimde kullanılmak üzere web erişimli veri tabanı yönetim sistemiyle ölçme ve değerlendirme sistemi tasarımı. TOJET. 2003;2(3):108.

2. Eroglu F, Kalaycı N. Üniversitelerdeki zorunlu ortak derslerden Türk dili dersinin uzaktan ve yüz yüze eğitim uygulamalarının karşılaştırılarak değerlendirilmesi. JOMTE. 2020;8(3):10011027. doi:10.16916/aded.710396.

3. Chen T, Peng L, Yin X, Rong J, Yang J, Cong G. Analysis of user satisfaction with online education platforms in China during the COVID-19 pandemic. In: Healthcare. vol. 8. Multidisciplinary Digital Publishing Institute; 2020. p. 200. doi:10.3390/healthcare8030200.

4. Chen T, Peng L, Jing B, Wu C, Yang J, Cong G. The impact of the COVID-19 pandemic on user experience with online education platforms in China. Sustainability. 2020;12(18):7329. doi:10.3390/su12187329.

5. Saracoglu AS, Kaslı AF. Öğretmen adaylarının bilgisayara yönelik tutumları ile basarıları arasındaki iliski. Ege Eğitim Dergisi. 2001;1(1).

6. Ertuğ C. Coronavirüs (Covid-19) pandemisi ve pedagojik yansımaları: Türkiye'de açık ve uzaktan eğitim uygulamaları. AUAD. 2020;6(2):11-53.

7. LaRose R, Gregg J, Eastin M. Audiographic telecourses for the Web: An experiment. JCMC. 1998;4(2):423. doi:10.1111/j.10836101.1998.tbooog3.x.

8. Rivera JC, Rice ML. A comparison of student outcomes and satisfaction between traditional and web based course offerings. JDLA. 2002;5(3):151-179. 